\title{
Corrigendum: Considerations for Phage Therapy Against Mycobacterium abscessus
}

\author{
OPEN ACCESS \\ Approved by: \\ Frontiers Editorial Office, \\ Frontiers Media SA, Switzerland \\ *Correspondence: \\ Jaime Esteban \\ jestebanmoreno@gmail.com \\ Specialty section: \\ This article was submitted to \\ Antimicrobials, Resistance and \\ Chemotherapy, \\ a section of the journal \\ Frontiers in Microbiology \\ Received: 09 June 2021 \\ Accepted: 10 June 2021 \\ Published: 14 July 2021 \\ Citation: \\ Senhaji-Kacha A, Esteban J and \\ Garcia-Quintanilla M (2021) \\ Corrigendum: Considerations for \\ Phage Therapy Against \\ Mycobacterium abscessus. \\ Front. Microbiol. 12:722831. \\ doi: 10.3389/fmicb.2021.722831
}

\author{
Abrar Senhaji-Kacha, Jaime Esteban* and Meritxell Garcia-Quintanilla \\ Department of Clinical Microbiology, IIS-Fundación Jiménez Díaz, Madrid, Spain
}

Keywords: Mycobacterium abscessus, non-tuberculous mycobacteria, phage therapy, alternative therapy, antibiotic resistance, bacteriophage

\section{A Corrigendum on}

Considerations for Phage Therapy Against Mycobacterium abscessus

by Senhaji-Kacha, A., Esteban, J., and Garcia-Quintanilla, M. (2021). Front. Microbiol. 11:609017. doi: 10.3389/fmicb.2020.609017

In the original article, we neglected to include the funders Instituto de Salud Carlos III and European Union, European Social Fund "Investing in your future" (CP19/00104) to MG-Q. The corrected Funding statement appears below.

MG-Q is supported by the Subprograma Miguel Servet from the Ministerio de Ciencia e Innovación of Spain, the Instituto de Salud Carlos III and the European Union, European Social Fund "Investing in your future" (CP19/00104).

The authors apologize for this error and state that this does not change the scientific conclusions of the article in any way. The original article has been updated.

Copyright $\odot 2021$ Senhaji-Kacha, Esteban and Garcia-Quintanilla. This is an open-access article distributed under the terms of the Creative Commons Attribution License (CC BY). The use, distribution or reproduction in other forums is permitted, provided the original author(s) and the copyright owner(s) are credited and that the original publication in this journal is cited, in accordance with accepted academic practice. No use, distribution or reproduction is permitted which does not comply with these terms. 